\title{
Chen v. Major League Baseball: Hybrid Collective Action Under Rule 23 and the Fair Labor Standards Act 216(b)
}

\author{
Sungho Cho and Joshua Smith
}

\begin{abstract}
Sport organizations frequently rely on volunteers and interns to operate various programs and events. While the use of such affordable or completely free labor has become an industry-wide practice, it may run afoul of the Fair Labor Standards Act, 29 U.S.C. § 201, et seq., and state labor law (Schoepfer \& Dodds, 2010). This article explores several procedural issues related to the hybrid collective action under Rule 23 of the Federal Rules of Civil Procedure and Fair Labor Standards Act 216(b) in light of a recent lawsuit filed against Major League Baseball, i.e., Chen v. Major League Baseball (2014). In Chen, a volunteer who worked for the MLB FanFest during the 2013 All-Star week argued that the league violated the law because it used volunteers for the fan festival without paying minimum wage. Various procedural aspects of such hybrid action are examined. A couple of defenses supported by recent U.S. Supreme Court decisions are introduced.
\end{abstract}

Volunteers and unpaid interns comprise a significant portion of labor force in the U.S. (Gregory, 1998; Jordan, 1993; Maye, 2013; Rubinstein, 2006), particularly, in the sport and entertainment industry (Schoepfer \& Dodds, 2010). While some internship programs run by sport and entertainment organizations might not be subject to the Fair Labor Standards Act of 1938 ("FLSA" hereafter) under the volunteer (29 U.S.C. $\S \S 203(\mathrm{e})(4)(\mathrm{A})$ ) or trainee exemption (Walling v. Portland Terminal Co., 1947), many others would still implicate with the law because courts have construed the trainee or volunteer exemption narrowly in light of the remedial characteristics of the statute (Glatt v. Fox Searchlight Pictures, 2013; Tony \& Susan Alamo Foundation v. Secretary of Labor, 1985). In the same vein, the FLSA is so paternalistic (Tony \& Susan Alamo Foundation v. Secretary of Labor, 1985) that employers and employees are not allowed to waive statutorily mandated rights under the law, e.g., minimum wage, overtime pay, even if the parties expressly agree so (Vadino v. A. Valey Engineers, 1990). The Department of Labor ("DOL" hereafter) recites such restrictive judicial interpretation by limiting the applicability of the trainee exemption (DOL, 2010). In addition, the volunteer exemption only applies to public agencies. A private for-profit enterprise may not use the exemption as a defense in FLSA litigation (Hallissey v. America Online, 2006).

Cho (scho@bgsu.edu) is with the School of HMSLS, Bowling Green State University, Bowling Green, $\mathrm{OH}$. Smith is with the Dept. of Intercollegiate Athletics, Old Dominion University, Norfolk, VA. 
During the last decade, there has been a $325 \%$ increase in wage-and-hour claims in federal courts (Sova, 2013). In particular, a growing number of FLSA actions have been filed against employers in the sport and entertainment industry (Bickerton v. Rose, 2012; Chen v. Major League Baseball, 2014; Davenport v. Elite Model Management Corp., 2013; Glatt v. Fox Searchlight Pictures, 2013; Wang v. Fento Fallon Corp., 2012; and Wang v. Hearst, 2013). In Glatt v. Fox Searchlight Pictures (2013), a group of interns working on the production of the movie "Black Swan" brought a so-called hybrid collective action under FLSA 216(b) and Rule 23 of the Federal Rules of Civil Procedure ("FRCP" hereafter) against Fox Searchlight in the U.S. District Court for the Southern District of New York. In the case, Fox Searchlight ran an internship program including individuals who essentially became necessary to carry out the operation of the business. The court applied six criteria promulgated by the DOL rather than a simplistic benefit test as had been used in Walling v. Portland Terminal Co. (1947). In applying the DOL test, the court found that even though the interns received some benefit from the experience, the employer was the primary beneficiary of the relationship (Glatt $v$. Fox Searchlight Pictures, 2013). The decision also indicated that had the interns not performed the tasks it would have been necessary to hire regular paid employees. Since the internship program failed to satisfy the DOL criteria, the court found the interns were actually employees of the defendant governed by the FLSA. As of this writing, the court granted both Rule 23 class certification and conditional certification for the collective action under the FLSA. The defendant immediately appealed the case to the Second Circuit.

In the area of FLSA class action, after a leading firm brings class actions that target an industry or pay practice, other law firms quickly follow the leader by filing copycat complaints against other employers (Sova, 2013). Given that the Glatt class was certified by the court, there would be a significant number of copycat lawsuits targeting entertainment and sport enterprises that heavily rely on services provided by unpaid interns and volunteers. In fact, the plaintiffs' bar already began to target the sport industry. In February 2014, three former minor leaguers brought a class action against Major League Baseball ("MLB" hereafter) under the California Labor Code and FLSA (Senne v. MLB, 2014). In the lawsuit, the plaintiffs portrayed minor leaguers as working poor based on various data. According to the complaint, many minor leaguers earn "between $\$ 3,000$ and $\$ 7,500$ for the entire year despite routinely working over 50 hours per week (and sometimes 70 hours per week) during the roughly five-month championship season" without overtime pay (Senne v. MLB, 2014, p. 2). To emphasize the exigency of the FLSA claim as the only viable legal recourse to minor leaguers, the complaint expounds that MLB still has the long standing exemption from antitrust scrutiny (Senne v. MLB, 2014 , p. 1). Essentially, Senne v. MLB is a progeny of Chen v. MLB (2013) where the plaintiff has been represented by a renowned class action law firm specialized in labor litigation, Outten \& Golden, LLP. The firm spearheaded the initial wave of FLSA class actions including Glatt v. Fox Searchlight (2013). In Chen, a volunteer, sued MLB for violations of the FLSA and equivalent state labor statute on behalf of himself and a putative class. The case is explained in detail later.

This article explores various aspects of the hybrid collective action under Rule 23 of the FRCP and FLSA 216(b) in light of a recent case, MLB v. Chen (2014). The second section of the article describes legislative history of FLSA and three 
FLSA exemptions that are frequently applied to sport and entertainment entities, i.e., volunteer exemption, trainee exemption, and amusement or recreational establishment exemption. The third section describes a recent FLSA class action filed against MLB, Chen v. MLB (2014). The factual background of the case is explained and the court decision is examined. The fourth section highlights a procedural snapshot of Rule 23 class certification and $\S 216$ (b) collective action. A couple of recent U.S. Supreme Court cases are introduced and defensive tactics are explained, i.e., Rule 23 class certification under Wal-Mart, Inc. v. Dukes (2011) and Rule 68 pick-off under Genesis Healthcare Co. v. Symczyk (2013). The last section provides some implications from the analysis.

\section{Fair Labor Standards Act}

\section{Legislative History}

In the early 20th century, the federal government and states attempted to pass minimum wage laws only to be rejected as violating substantive due process (Adkins v. Children's Hospital, 1923). Finally, in 1937 the U.S. Supreme Court reversed course in West Coast Hotel Co. v. Parrish (1937) and found that minimum wage laws were compatible with due process of law (Jordan, 1993). The decision in West Coast Hotel was a seminal employment law case that occurred during a period when employer abuse and unemployment were widespread. Within months, Congress began to draft a bill proposal that would create a comprehensive federal statute covering child labor and minimum standards of employment (Jordan, 1993).

The Fair Labor Standards Act, 29 U.S.C. $§ \S 201$ et seq., was enacted by Congress in an attempt to eliminate detrimental and coercive labor conditions (Cleary, 1995). The preamble indicates that the law intends to "provide for the establishment of fair labor standards in employments in and affecting interstate commerce." To accomplish this objective, the FLSA establishes a minimum wage to be paid to employees and overtime pay required after a maximum number of hours among other requirements. The FLSA also details numerous exemptions that allow employers to avoid the legal implications under the Act in situations that do not fit into the legislative intent. The Act, however, did not address employment issues such as vacation time, sick pay, raises, or fringe benefits (Murphy \& Azoff, 1987).

To fall within the reach of the Act an industry must engage in interstate commerce or in the production of goods for interstate commerce (29 U.S.C. $\$ \S 202(a)$ ). Since nearly every enterprise engages in interstate commerce and both public and private sector employees are covered, Congress has carved out various exceptions mostly under $\S 213$ that would not unjustly cause an employer to be bound by the statute. While more than 40 exemptions exist, the most commonly used ones include executive, administrative and outside sales employees, farmworkers, trainees, volunteers and employees of seasonal and recreational establishments.

\section{Volunteer Exemption}

Two common groups of individuals exempt from the FLSA wage and overtime requirements are trainees and volunteers. An individual is covered under the Act only if he or she is determined to be an employee (Rubinstein, 2006). An "employee" 
under the FLSA does not include an individual who volunteers at a state agency, political subdivision or a state or an interstate governmental agency if "(i) the individual receives no compensation ... or a nominal fee to perform the services . . . and (ii) such services are not the same type of services which the individual is employed to perform for such public agency" (29 U.S.C. §§ 203(e) (4)(A)(i-ii)). An individual who volunteers solely for humanitarian purposes to private nonprofit food banks is also exempt from the employee definition (29 U.S.C. $\S \S 203(\mathrm{e})(5))$.

The definition of volunteer is articulated under the DOL's regulation, 29 C.F.R. $§ 553.101(a)$ : “[a]n individual who performs hours of service for a public agency for civic, charitable, or humanitarian reasons, without promise, expectation or receipt of compensation for services rendered, is considered to be a volunteer during such hours." The DOL examines three factors to determine whether an individual is a volunteer rather than an employee: (1) who receives the benefits of the individual's work; (2) how long it takes to render the services; and (3) whether the services are typical volunteer activities (Kalet, 1990) in accordance with Tony \& Susan Alamo Foundation v. Secretary of Labor (1985). Volunteer services must be "offered freely and without pressure or coercion, direct or implied, from an employer" (29 C.F.R. § 553.101(c)).

Examples of those who fall under the volunteer exception of FLSA include members of civic organizations helping out in a sheltered workshop; parents volunteering to drive a school bus to carry students on a trip; students volunteering at nursing homes and hospitals; helping youth programs as camp counselors and other services needed to carry out charitable, educational or religious programs (DOL, 2009). Under the FLSA, it is not permissible to volunteer services to for-profit private sector employers (DOL, 2009) since this exemption exclusively applies to public agencies. For-profit enterprises may not use the exemption as an affirmative defense in FLSA litigation (Hallissey v. America Online, 2006).

The U.S. Supreme Court has examined the issue of volunteer exemption in Tony \& Susan Alamo Foundation v. Secretary of Labor (1985). In Tony \& Susan Alamo, the DOL brought an action under the FLSA against a nonprofit religious corporation that was engaged in an array of commercial activities, e.g., running hog farms, service stations, restaurants, and retail stores. The organization operated the commercial establishments by recruiting volunteers who were mostly homeless, drug addicts, or criminals before their rehabilitation. The organization did not pay the individuals but provided basic necessities such as food, clothing, shelter, medical care, etc. In response to the DOL's FLSA claim, the foundation alleged that their staff are in fact volunteers exempt from the statute. In addition, the foundation argued that the DOL's application of the FLSA to the activities violates the free exercise clause of the First Amendment.

In Tony \& Susan Alamo, the Court announced that the minimum wage and overtime provisions of the FLSA would not reach ordinary volunteerism. The court listed three factors considered to determine whether an individual is an employee or volunteer: "the receipt of any benefits from those for whom the services are performed, whether the activity is a less than full-time occupation, and whether the services are of the kind typically associated with volunteer work" (Tony \& Susan Alamo Foundation v. Secretary of Labor, 1985, p. 303). By implementing the three-factor analysis, the Court unanimously found that the staff were not 
volunteers but employees of the foundation since they worked for the employer with the expectation of receiving substantial in-kind "benefits in exchange for" their labor (Tony \& Susan Alamo Foundation v. Secretary of Labor, 1985, p. 304). The Tony \& Susan Alamo three factors have been adopted by the DOL and incorporated into the previously mentioned DOL test to determine whether an individual is an employee or a volunteer. In regards to the foundation's First Amendment defense, the court ruled that the DOL's charge under the FLSA was consistent with the requirements of the First Amendment clause since the staff could have given back their wages to the foundation freely had they been paid by the employer (Tony \& Susan Alamo Foundation v. Secretary of Labor, 1985, p. 292).

\section{Trainee Exemption}

Another similar exemption is that of trainees, those who most often participate in internships. A seminal case was the 1947 decision in Walling v. Portland Terminal Co. (1947). In Walling, a railroad employer provided workers with practical training as prospective yard brakemen. The trainees were required to complete a one week, unpaid training course before accepting an application for employment. In upholding the lower court's ruling that the trainees were not due wages for the course of training, the U.S. Supreme Court held that the definition of employ and employee should not be interpreted so broadly as to encompass those persons whose work only serves his own interest with the enterprise receiving no immediate advantage (Walling v. Portland Terminal Co., 1947). After Walling, courts began narrowing their interpretation of "employee" to allow more individuals to meet the trainee/ volunteer exception. For instance, in 1971, Isaacson v. Penn Community Services, Inc. (1971) decided that a conscientious objector working at a nonprofit corporation was not subject to FLSA as the nonprofit corporation derived no immediate advantage from the work being performed. Isaacson qualified and elaborated the Walling analysis by shifting the focus from who received the exclusive benefit to who received the principal benefit (Jordan, 1993).

Eventually, the DOL (2010) has established six criteria in determining whether an internship or training program meets the trainee exception. The test is remarkably more stringent than Walling and other judicial tests because an individual must meet all six of the criteria to be recognized as a trainee:

1. the internship, even though it includes actual operation of the facilities of the employer, is similar to training which would be given in an educational environment

2. the internship experience is for the benefit of the intern

3. the intern does not displace regular employees, but works under close supervision of existing staff

4. the employer that provides the training derives no immediate advantage from the activities of the intern, and on occasion its operations may actually be impeded

5. the intern is not necessarily entitled to a job at the conclusion of the internship

6. the employer and the intern understand that the intern is not entitled to wages for the time spent in the internship. (DOL, 2010) 
In Glatt v. Fox Searchlight Pictures, although the defendant argued the Walling test as the method of analysis, the court applied the DOL test and found that the plaintiff was an employee.

In recent years many employers require school credits for their internship programs to recruit and employ interns without triggering FLSA implications. At minimum, such practice would allow employers to meet the first criterion of the DOL test. Nevertheless, the agency and courts have looked beyond the fulfillment of academic course credits when they investigate whether an individual is an employee for the purpose of the FLSA and other labor statutes (Schoepfer \& Dodds, 2010).

The FLSA volunteer and trainee exemptions are not easily applicable since the statutory definition of "employee" under the law is "exceedingly broad" (Tony \& Susan Alamo Foundation v. Secretary of Labor, 1985, p. 295). The Act defines an "employee" as "any individual employed by an employer" (29 U.S.C. § 203(e) (1)). "Employ" is defined as "to suffer or permit to work" (29 U.S.C. § 203(e)(2) (B)). In Hill v. U.S., the Sixth Circuit Court of Appeals defined "work" as "physical or mental exertion for employer's benefit as well as standby or waiting time" (Hill v. U.S., 1984, p. 812). Simply speaking, when an employer "suffers" or "permits" another person to work, there is an employment relationship under the FLSA regardless of the parties' intention (Murphy \& Azoff, 1987). Courts have routinely scrutinized beyond the label of employment relationship named by employers and applied "totality of the circumstances" to determine employee status pursuant to the FLSA (Cleveland v. City of Elmendorf, 2004, p. 529).

Recently, multiple FLSA class actions have been filed with various district courts that will likely have a profound impact on the future of internship practices and volunteer programs in the sport and entertainment industry (See Bickerton $v$. Rose, 2012; Chen v. MLB, 2013; Davenport v. Elite Model Management Corp., 2013; Senne v. MLB, 2014; Wang v. Fento Fallon Corp., 2012; and Wang v. Hearst, 2013).

\section{Amusement or Recreational Establishment Exemption}

The FLSA provides an exemption to the minimum wage and overtime provision where an employee is "employed by an establishment which is an amusement or recreational establishment ... if (A) it does not operate for more than seven months in any calendar year, or (B) during the preceding year, its average receipts for any six months of such year were not more than $331 / 3$ per centum of its average receipts for the other six months of such year" (29 U.S.C. § 213(a)(3)). Although the statute does not provide a clear definition of an "establishment," Section 203(r) distinguishes an "establishment" from an "enterprise."

Enterprise means the related activities performed (either through unified operation or common control) by any person or persons for a common business purpose, and includes all such activities whether performed in one or more establishments or by one or more corporate or other organizational units. (29 U.S.C. $\S 203(r))$

In consideration of $\S 203(\mathrm{r})$, the DOL's regulation defines an "establishment" as "a distinct physical place of business" as opposed to "an entire business or enterprise" which may include several separate places of business (29 C.F.R. $\S$ 779.23; 29 C.F.R. $§ 779.203)$. 
The $\$ 213(\mathrm{a})(3)$ seasonal exemption has been examined by courts in a trio of baseball cases. In Jeffery v. Sarasota White Sox (1995) the plaintiff groundskeeper sought damages for unpaid overtime against the owner of a minor league baseball franchise. The defendant conducted its baseball operations at the facility from April through August each year with the plaintiff serving in his capacity as an employee during those months (Jeffery v. Sarasota White Sox, 1995). In its motion for summary judgment, the defendant claimed that the baseball franchise was not required to pay overtime because the entity was an amusement or recreational establishment under the seasonal exemption. In deciding in favor of the defendant, the court found that the employer was entitled to the exemption based on the length of its seasonal operation lasting less than seven months. The plaintiff argued that his employment lasted into the off-season months to prepare the field before the arrival of teams for spring training. The court found, however, that the " $[\mathrm{t}]$ he focus on the exemption is not on the length of time Plaintiff performed his work. Rather, the focus is on length of the Defendant's seasonal operation" (Jeffery v. Sarasota White Sox, 1995, p. 596).

The second baseball case, Adams v. Detroit Tigers (1997), was adjudicated two years later. The U.S. District Court for the Eastern District of Michigan followed a similar path in finding a professional baseball team's batboys were not due damages for unpaid overtime and minimum wages. The plaintiffs were batboys for the Detroit Tigers, a baseball team conducting business from April into October. The plaintiffs were paid $\$ 45$ per day regardless of the length of work days or amount of work completed. While the defendant did not completely shut down its business during the off-season (November through March) the stadium was closed to the public. The Tigers also argued that their average monthly receipts for the six months with the lowest receipts were less than $331 / 3 \%$ of the average monthly receipts of the six months with the highest receipts. Since the FLSA seasonal exemption does not require the average receipts to be from consecutive months, the court accepted the defendant's claim as meeting the exception.

In Adams, the plaintiffs did not contest the determination of the employer as a recreation or amusement establishment but tried to distinguish their employment as a separate establishment within the organization. The plaintiffs argued that they should be viewed similar to that of employees within the administrative offices of a sport team. The court found, however, that the batboys only work home games and do nothing that resembles the office duties of administrative staff. The defendant was granted summary judgment since it was able to show an average of six months of receipts being less than $331 / 3$ per cent of the average of receipts for the remainder of the year under $\S 213(\mathrm{a})(3)$ exemption.

In contrast, the Sixth Circuit found that a baseball franchise may not qualify as a seasonal establishment (Bridewell v. Cincinnati Reds, 1998). In Bridewell, a group of maintenance workers brought FLSA claims against the team when their overtime pay was denied. After the District Court decided for the plaintiffs, the defendant sought on appeal an examination of the seasonal exemption under $\S$ 213(a)(3). The Reds alleged that the enterprise operated for less than seven months or, alternatively, its average receipts from the six month off-season do not amount to more than $331 / 3 \%$ of its average receipts during the six month season.

In examining the case, the Sixth Circuit immediately rejected the argument that the appellant's operation of business was for less than seven months in a calendar year. With respect to the issue of average receipt, the Cincinnati Reds 
asked the court to interpret the team's term receipt based on an accrual method of accounting whereby the company receives income during the off-season but does not record the income until the game is actually played. The appellant argued that such accrual method was more reliable to match revenues with expenses than the cash-based accounting which requires the company to record an amount of income whenever it is actually received. In upholding the lower court's decision to apply the cash-based accounting as the method that more accurately reflects plain language of the Act, the Sixth Circuit refused to accept the accrual method argued by the team for the exemption. Since the average receipts estimated under the cash-based method from the six month off-season period amounted to more than $331 / 3 \%$, the Cincinnati Reds organization was not exempt from providing overtime pay to its employees under the law.

\section{Chen V. Major League Baseball}

\section{Case Facts}

In August 2013, John Chen who worked as a volunteer for the 2013 MLB All-Star FanFest, a fan festival held in and around the City of New York during 2013 MLB All-Star week, brought a Rule 23 class action as well as FLSA collective action against the league on behalf of himself and "all others similarly situated" under Rule 23 and FLSA (FLSA $\S 216($ b)). The plaintiff alleged that MLB staffed the for-profit promotional event "almost entirely with volunteers and did not pay them" minimum wages statutorily mandated by the FLSA and New York Labor Laws (Chen v. MLB, 2013, p. 2). Through the federal and state law claims, in essence, the plaintiff sought to: "(1) force MLB to stop soliciting and accepting work from unpaid volunteers, (2) allow those who cannot afford to work for free to work at FanFest and other events related to the All-Star Game, and (3) recover unpaid wages for all unpaid volunteers who performed work for MLB during the relevant period" (Chen v. MLB, 2013, p. 2).

The plaintiff's complaint portrayed that while the period of the event was brief (July 12-16, 2013), it was clearly a for-profit commercial event designed to promote the league. MLB advertised the event as "the largest interactive baseball theme park in the world," "baseball heaven on earth," etc. (MLB.com, 2014). The league charged all adults $\$ 35.00$ and children two years and older $\$ 30.00$ for entrance. Paying customers could purchase "a bag of potato chips for $\$ 5.00$ and a cup of lemonade for \$7.50" (Chen v. MLB, 2013, p. 4). No outside food or beverage was allowed in the premise (MLB.com, 2014). The league solicited corporate sponsorships by stating that "[b]aseball fans of all ages are expected to attend 2013 MLB All-Star FanFest, and your organization will have the ideal venue to leverage the most eagerly awaited fan experience of the summer" (Chen v. MLB, 2013, p. 4). Various events during the All-Star weekend were sponsored by large corporations including T-Mobile, Taco Bell, SiriusXM, Gatorade, Majestic, Blockbuster, Kellogg's, Gillette, Head \& Shoulders, One A Day, Firestone, Scotts, Chevy, Duane Reade, New Era, Budweiser, Party City, and Under Armour (Chen v. MLB, 2013). MLB stated that the 2013 All-Star Game and related events, e.g., 2013 MLB All-Star FanFest "brought approximately $\$ 191.5$ million into the New York City economy" (Chen v. MLB, 2013, p. 5). 
In Chen, MLB allegedly recruited approximately 2000 volunteers (MLB.com, 2014) to "operate 40 attractions" during the 2013 All-Star Game weekend for various events including the 2013 MLB All-Star FanFest (Chen v. MLB, 2013, p. 5). MLB.com (2014) indicates that all volunteers were required to attend an unpaid mandatory information session and orientation session. If volunteers could not complete any mandatory information session, they were not allowed to work at the site (Chen v. MLB, 2013; MLB.com, 2014). Instead of paying minimum wages mandated under the federal and state labor law, MLB provided volunteers with a shirt, a cap, a cinch drawstring backpack, free admission for the volunteer and one guest to the MLB All-Star FanFest during off-duty hours, a water bottle, a baseball, and a chance to win one pair of All-Star Game tickets if they worked three shifts at any of the All-Star events (MLB.com, 2014).

The plaintiff's claim was based on two divergent federal and state statutory grounds, i.e., the FLSA collective action under $\$ 216$ (b) and FRCP Rule 23 class action pursuant to the New York Labor Law Article 6, §§ 190 et seq., Article 19, $\S \S 650$ et seq., and New York State Department of Labor Regulations, N.Y. Comp. Codes Rule \& Regulations, Title 12, Part 142 et seq. ("NYLL" hereafter). The court had original subject matter jurisdiction with respect to the FLSA collective action under 28 U.S.C. $\$ \S 1331$ and 1337, and supplemental jurisdiction over the state law claim under 28 U.S.C. $\$ 1367$ (Chen v. MLB, 2013). The procedural snapshot of such type of hybrid collective action is described in the next section.

While the FLSA contains a 2 year statute of limitation in general and 3 years for willful violations (29 U.S.C. § 255(a)), the NYLL allows a 6 year statute of limitation. Hence, there were two different classes in Chen. The plaintiff defined the FLSA collective action class as "himself and all persons who have worked as unpaid volunteers for MLB between August 7, 2010 and the date of final judgment in this matter" (Chen .v MLB, 2013, p. 12). On the other hand, the Rule 23 class in conjunction with the state law claims included the plaintiff himself and "all persons who have worked and unpaid volunteers for MLB in New York between August 7 , 2007 and the date of final judgment" in the lawsuit (Chen v. MLB, 2013, p. 10). On August 15, 2013, eight days after the filing of the complaint, the plaintiff swiftly moved for the conditional certification of the FLSA class and court-authorized notice to the proposed putative group of "similarly situated" individuals pursuant to 29 U.S.C. $§ 216$ (b). The defendant filed Rule 12(b)(6) motion to dismiss the plaintiff's complaint for failure to state a claim upon which relief can be granted under the FRCP Rule 12(b)(6).

\section{Decision}

In examining the defendant's 12(b)(6) motion in conjunction with the plaintiff's motion for conditional certification and notice pursuant to the FLSA § 216(b), on March 25, 2014, the court decided for the defendant. In the case, the defendant proffered two bases why the plaintiff's FLSA claim must be denied. First, the defendant argued that Chen is not an "employee" as defined in the FLSA provisions, i.e., 29 U.S.C. $§ 203(\mathrm{e})(1)$ and 206(a). Second, MLB argued that even if Chen is an employee, the plaintiff is still not entitled to the FLSA remedies since he worked 
for an "amusement or recreational establishment" that is exempt from the statute under 29 U.S.C. $\$ 213(\mathrm{a})(3)$ (Chen v. MLB, 2014, p. 5). The District Court analyzed the case by focusing on the second ground, "an amusement or recreational establishment" exemption under $\S 213(\mathrm{a})(3)$. Thus, the court decision did not reach to the inquiry of whether the plaintiff is properly classified as an employee or volunteer.

The plaintiff countered the defendant's "amusement or recreational establishment" defense based on two grounds, a substantive and a procedural one. Substantively, the plaintiff contended that the exemption must not be applied to the case since Chen was employed not by the 2013 MLB All-Star FanFest, but by MLB, which is an "establishment" in operation for more than eight months in 2013 for the purpose of $\S 213$ (a)(3) exemption. The plaintiff pointed out a couple of FLSA cases where baseball franchises were scrutinized as establishments (Jeffery $v$. Sarasota White Sox, 1995; Bridewell v. Cincinnati Reds, 1998). Although Jeffery and Bridewell respectively examined two different prongs of the seasonal establishment exemption, i.e., $\S 213(\mathrm{a})(3)(\mathrm{A})$ and (B), the unit of examination and analysis in both cases was the baseball team instead of the individual sites where the plaintiffs were physically present and worked. Procedurally, Chen contested that it would be inappropriate to dismiss the FLSA claim in such early stage of the litigation based on Rule 12(b)(6) because the seasonal establishment exemption is an affirmative defense. Thus, the plaintiff argued that the party must be allowed to conduct discovery to prove or disprove the defendant's affirmative defense (Chen v. MLB, 2014).

As such, while both parties agreed that baseball is clearly "amusement or recreational," the central dispute was the meaning of the term, "establishment" in the exemption. The court admitted that the statutory language of FLSA does not provide a precise definition of "establishment" for the seasonal establishment exemption. Given the absence of statutory definition, the court shifted its focus to the DOL's regulation. According to the agency's regulation, an establishment is defined as "a distinct physical place of business" whereas an "enterprise" is "an entire business or enterprise which may include several separate places of business" (29 C.F.R. $\S$ 779.23; 29 C.F.R. $§ 779.203$ ). Given the DOL definition, the court declared that Chen was employed by the MLB All-Star FanFest, which is an "establishment" operated less than one week rather than MLB at Park Avenue in Manhattan, New York. The opinion pointed out that "for the purpose of [\$213(a)(3)], an individual is employed by the establishment at which he works, regardless of any enterprise that may operate or control the establishment" (Chen v. MLB, 2014, p. 22). In response to the plaintiff's procedural argument, the court explained that this case might be an exceptional one because a Rule 12(b)(6) motion relying on FLSA exemptions might be successful "only if the exemption appears on the face of the complaint" (Pani v. Empire Blue Cross Blue Shield, 1998, p. 74) and Chen's complaint indeed supported the defendant's Rule 12(b)(6) motion.

As the court dismissed the FLSA claim, the plaintiff's motion for conditional class certification and court-authorized notice under 216(b) was also dismissed as moot. In addition, the court declined to exercise its supplemental jurisdiction over the state law claim. Therefore, the Rule 23 class action claim was dismissed without prejudice. 


\section{Aftermath of Chen}

Although MLB successfully dismissed the plaintiff's FLSA claim at the early stage of the lawsuit, the repercussion of Chen was remarkable. At minimum, the case demonstrated that various internship and volunteer programs in the sport and entertainment industry might be subject to the FLSA. The case urged sport and entertainment organizations to be more proactive than reactive in dealing with unpaid interns and volunteers. In February 2014, the National Football League ("NFL" hereafter) opted to hire approximately 10,000 part-time workers to meet and greet football fans during the Super Bowl fan festivities in New York and New Jersey, presumably, influenced by Chen. In previous years, the NFL had mostly used unpaid volunteers for similar kinds of promotional events (Calder, 2014, March 26).

Even though MLB successfully defended in Chen, the kind of dispute might be far from the end. Actually, the District Court decision in Chen poses more questions than answers for sport enterprises. First, the plaintiff's Rule 23 state law claim was dismissed without prejudice. Theoretically, the plaintiff's state claim can be retried since there is no preclusive effect from the District Court's decision. Second, the plaintiff timely raised appealable issues during the brief period of litigation. Substantively, it might be arguable that the court's interpretation of the $\$ 213(\mathrm{a})(3)$ exemption would likely frustrate the entire statutory scheme of the FLSA by significantly limiting the scope of employment relationship subject to the law. For instance, according to Chen, a field technician who continuously and regularly works at multiple event sites for a big event management firm might not have FLSA claims for minimum wage.

Procedurally, Rule 12(b)(6) motion for an affirmative defense may not be granted unless the exemption "appears on the face of the complaint" (Pani $v$. Empire Blue Cross Blue Shield, 1998, p. 74). Although Chen's complaint mentioned that the defendant had promoted the FanFest as "theme park," and sporadically described Chen's daily responsibilities as an unpaid worker at the site, the complaint substantially focuses on MLB's macro-level event management practices rather than site-specific operation. Given the fact that the $\S 213$ (a)(3) exemption is an affirmative defense, it is possible that the Second Circuit would overturn the district court's decision on the Rule 12(b)(6) motion as premature and remand the case back to the trial court.

Third, even if Chen decides not to appeal, copycat complaints might be filed against a variety of sport and entertainment organizations that would not qualify the seasonal exemption or other FLSA defenses. In consideration of the "shot-gun" approach that is widely practiced in the area of class action litigation, it might not be highly likely that the same law firm immediately appeals the case to the Second Circuit. Instead, the firm would initiate similar FLSA claims with stronger facts against other sport or entertainment organizations or attempt to file another lawsuit against MLB for the remaining Rule 23 state law claim. In addition, other law firms and lawyers may bring the second wave of isomorphic FLSA class actions with copycat complaints following Chen and Glatt that targeted the sport and entertainment industry.

Given the significance of the FLSA collective action mechanisms at issue, it might be useful to explore several aspects of the hybrid action under the FLSA and FRCP Rule 23. The following section covers the subject. 


\section{Hybrid Action Under Rule 23 and 216(b), Dukes, and Genesis Healthcare}

\section{Rule 23 Class certification}

The Federal Rules of Civil Procedure (FRCP) was promulgated under the Rules Enabling Act, 28 U.S.C. $§ 2072$, to govern civil procedure within federal courts. FRCP Rule 23 pertains to the requirements for a civil action to be certified as a class action. Rule 23(a) is a prerequisite for a class certification. It states, "one or more members of a class action may sue or be sued as representative parties on behalf of all members only if

1. the class is so numerous that joinder of all members is impracticable

2. there are questions of law or fact common to the class

3. the claims or defenses of the representative parties are typical of the claims or defenses of the class

4. the representative parties will fairly and adequately protect the interests of the class.” (Fed. R. Civ. P. 23(a))

The Rule 23(a) requirements are known as numerosity, commonality, typicality and adequate representation. Even though there is no magic number that will automatically satisfy the numerosity requirement (Gillis v. Hoechst Celanese Corp., 1992), "mere allegations of numerosity are insufficient to meet this prerequisite" (Evans v. U.S. Pipe \& Foundry Co., 1983, p. 930). The majority of courts are similar in allowing the moving party to provide some evidence of a reasonable estimate of the overall number of class members (Smith v. Aon Corp., 2006; Tittle v. Enron Corp., 2005). The "impracticability" under Rule 23(a)(1) does not require "impossibility, but only the difficulty or inconvenience of joining all members of the class" Harris v. Palm Springs Alpine Estates (1964, p. 913-914).

The commonality requirement is established if the plaintiffs' and class members' grievances share a common question of law or fact (Banyai v. Mazur, 2002). "Commonality requires the plaintiff to demonstrate that the class members have suffered the same injury" (General Telephone Co. v. Falcon, 1982, p. 157). Only one common question of law is necessary to meet the commonality requirement (Richards v. FleetBoston Fin. Corp., 2006). The question of law or fact must be at the core of the cause of action and able to be solved in an identical matter (Babcock v. Computer Assocs. Int'l, 2003; Bellas v. CBS, Inc., 2000). The U.S. Supreme Court further clarified the concept of commonality in Wal-Mart, Inc. v. Dukes:

This does not mean merely that they have all suffered a violation of the same pro-vision of law . . . [rather] their claims must depend upon a common contention ... of such a nature that it is capable of classwide resolution-which means that determination of its truth or falsity will resolve an issue that is central to the validity of each one of the claims in one stroke. (2011, p. 2551)

The typicality requirement of Rule 23(a) is intended to assure both plaintiff and defendant members are not involved in unwarranted adjudication (Guarino, 1985). Typicality is generally met if there is no antagonism between the claims 
of the class representative and other members of the class (Guarino, 1985). This requirement usually demands a plaintiff to demonstrate that there is a sufficient nexus between the claims of the named representative and those of the class at large (Thompson v. RelationsServe Media, Inc., 2010). In addition, "[t]he typicality requirement may be satisfied despite substantial factual differences ... when there is a strong similarity of legal theories" (Williams v. Mohawk Industry, Inc., 2009, p. 1357; citing Murray v. Auslander, 2001, p. 811).

The adequate representation means that the entire class must be fairly represented by a small number of leading plaintiffs (Eisen v. Carlisle \& Jacquelin, 1968) and a competent counsel. Since class members are bound by any judgment decided in a Rule 23 class action unless they opt out, this prong addresses the due process concerns of unnamed class members (Matsushita Electric Industrial, Co. v. Epstein, 1996). The element also requires the competency of class counsel who has no conflict of interest between class representatives and members of the proposed class (Wal-Mart, Inc. v. Dukes, 2011).

In Wal-Mart, Inc. v. Dukes (2011), the U.S. Supreme Court called attention that the Rule 23(a) commonality, typicality, and adequate representation requirements tend to merge with each other as all three "serve as guideposts for determining whether under the particular circumstances maintenance of a class action is economical and whether the named plaintiff's claim and the class claims are so interrelated that the interests of the class members will be fairly and adequately protected in their absence" (Wal-Mart, Inc. v. Dukes, 2011, p. 2551; citing General Telephone Co. v. Falcon, 1982).

In addition to Rule 23(a), plaintiffs must satisfy one of three prongs of Rule 23(b). Class actions for damages are generally governed by Rule 23(b)(3) that requires "predominance and superiority" (Amchem Products, Inc. v. Windsor, 1997). Rule 23(b)(3) states

[T] he court finds that the questions of law or fact common to class members predominate over any questions affecting only individual members, and that a class action is superior to other available methods for fairly and efficiently adjudicating the controversy. The matters pertinent to these findings include: (A) the class members' interests in individually controlling the prosecution or defense of separate actions; (B) the extent and nature of any litigation concerning the controversy already begun by or against class members; $(C)$ the desirability or undesirability of concentrating the litigation of the claims in the particular forum; and (D) the likely difficulties in managing a class action. (Fed. R. Civ. P., Rule 23(b)(3))

The U.S. Supreme Court recently articulated that the party seeking class certification must "affirmatively demonstrate" that all requirements of Rule 23(a) are met, and that the class is maintainable pursuant to Rule 23(b) (Wal-Mart, Inc. v. Dukes, 2011, p. 2551).

\section{FLSA 216(b) and Hybrid Class Action}

A FLSA claim for minimum wages or overtime violation may not be pursued as a traditional Rule 23 class action. The only procedural mechanism for collective litigation of FLSA claims is $\S 216$ (b) collective action. The statute provides 
An action to recover the liability prescribed in either of the preceding sentences may be maintained against any employer (including a public agency) in any Federal or State court of competent jurisdiction by any one or more employees for and in behalf of himself or themselves and other employees similarly situated. No employee shall be a party plaintiff to any such action unless he gives his consent in writing to become such a party and such consent is filed in the court in which such action is brought. (29 U.S.C. § 216(b))

Section 216(b) was enacted in response to "excessive litigation spawned by plaintiffs lacking a personal interest in the outcome" (Hoffman-La Roche, Inc. $v$. Sperling, 1989, p. 173). As the provision mandates, plaintiffs must affirmatively "opt-in" to participate in the lawsuit whereas Rule 23 class members are automatically included unless they "opt-out." In addition, while Rule 23 class certification is primarily governed by the statutory provisions, the certification standards under $\S 216$ (b) have been developed judicially (Hoffman-La Roche, Inc. v. Sperling, 1989). While circuits have developed different procedural standards, there are two separate stages in FLSA collective action certification in general, i.e., "notice" or "conditional certification" (Stage 1) and "decertification" (Stage 2) in general.

In Stage 1, courts would likely determine: (1) the contour and size of the putative group of employees that may be represented in the lawsuit; and (2) whether the members of the collective action described in the pleadings are "similarly situated" (Adler \& Prentice, 2012; Laroque v. Domino's Pizza, LLC, 2008). This process is clearly more lenient than the class certification under FRCP Rule 23. "Generally plaintiffs can satisfy the similarly situated requirement by making a modest factual showing sufficient to demonstrate that they and potential plaintiffs together were victims of a common policy or plan that violated the law" (Realite v. Ark Restaurants Corp., 1998, p. 306; emphasis added). In contrast, although plaintiffs bear a minimal burden to satisfy the similarly situated standard at Stage 1, they may not merely rely on the allegations in their complaints (Grayson v. K Mart Corp., 1996).

Stage 2 is more stringent similar to the Rule 23 class certification. It typically occurs at the conclusion of the discovery upon which the defendant files the motion for decertification (Smith \& Jalbert, 2011). This stage determines whether the plaintiffs and opt-in plaintiffs are similarly situated by using more rigorous standards. Courts usually inquire into: "(1) disparity or similarity of the factual and employment settings of the individual plaintiffs; (2) the various defenses available to the defendant and whether those may be asserted collectively or individually as to each plaintiff; and (3) fairness and procedure considerations" (Smith \& Jalbert, 2011, p. 6; Nerland v. Caribou Coffee Co., 2007).

The number of hybrid collective actions filed in federal courts pursuant to both Rule 23 and $\S 216$ (b) has been growing exponentially (Cheskin, Samuel, Cheung, \& Burke, 2006; Spelfogel, 2009) presumably because such type of action is arguably plaintiff-friendly. In fact, the 216(b) conditional certification is not so demanding compared with Rule 23. When the conditional certification is granted by the court, plaintiffs have access to the identities and contact information of the putative class members that can be used continuously throughout the litigation without further discovery request. In addition, when the court-authorized notice is sent out, the case would likely be publicized so that it may allow plaintiffs to build more leverage in settlement negotiation. 
Occasionally, § 216(b) collective action and Rule 23 class action are complementary. Most circuits have ruled that Rule 23 class actions and FLSA collective actions are mutually exclusive and irreconcilable (Grayson v. K-Mart, 1996). Therefore, the federal preemption (Altria Group v. Good, 2008) or "inherent incompatibility" argument (Knepper v. Rite Aid Corp., 2012) has not been generally successful in most jurisdictions. In Chen v. MLB, even though the defendant managed to dismiss the plaintiff's FLSA claim under the seasonal establishment exemption, there is no such affirmative defense under the state law. With respect to the Rule 23 state law claim, the court in Chen simply refused to exercise its supplemental jurisdiction. Thus, the state law claim was dismissed without prejudice. The plaintiff can retry the case in any courts with competent jurisdiction since there is no preclusive effect from the decision.

State labor laws are from time to time more favorable to plaintiffs. In Chen, the putative class for Rule 23 claim was significantly larger than the FLSA collective action class since the NYLL provides a six year statute of limitation whereas the FLSA statute of limitation is two years (three years for willful violations). Moreover, under Rule 23, the statute of limitation is tolled as to all putative class members upon filing of the complaint. In the FLSA collective action, however, the statute of limitation as to all putative individual claimants continues to run unless they affirmatively file the consent to opt-in (29 U.S.C. $§ 256(b))$.

\section{Defenses to Hybrid Collection Action Claims}

While there is a number of substantive and procedural defenses available against the hybrid collective action under Rule 23 and $\$ 216$ (b) depending on particularities of individual cases, two defensive tactics are noteworthy in consideration of recent U.S. Supreme Court decisions, i.e., the heightened standards for class certification under Wal-Mart, Inc. v. Dukes (2011) and Rule 68 "pick-off” under Genesis Heathcare, Co. v. Symczyk (2013).

Rule 23 Class Certification: Wal-Mart, Inc. v. Dukes (2011). In 2011, the U.S. Supreme Court in Wal-Mart, Inc. v. Dukes articulated the heightened standards of Rule 23 class certification. In Dukes, three current and former female employees of Wal-Mart had alleged gender discrimination under Title VII of the Civil Rights Act of 1964. The plaintiffs sought injunctive relief, declaratory relief, and back pay allegedly incidental to the injunctive relief. The Ninth Circuit affirmed the District Court's class certification under Rule 23(b)(2), which allowed class treatment of claims where "the party opposing the class has acted or refused to act on grounds that apply generally to the class, so that final injunctive relief or corresponding declaratory relief is appropriate respecting the class as a whole" (Fed. R. Civ. P. Rule 23(b)(2)). The U.S. Supreme Court (5-4) reversed the Ninth Circuit decision that had certified the nationwide class action encompassing 1.5 million former and current female Wal-Mart employees (Wal-Mart, Inc. v. Dukes, 2011).

In Dukes, the Court declared that "Rule 23 does not set forth a mere pleading standard. A party seeking class certification must affirmatively demonstrate his compliance with the Rule ... certification is proper only if the trial court is satisfied, after a rigorous analysis, that the prerequisites of Rule 23(a) have been satisfied" (Wal-Mart, Inc. v. Dukes, 2011, p. 2551). The Court held that the Ninth Circuit had misapplied the commonality standard of Rule 23 class action. The opinion states 
that "[c]ommonality requires the plaintiff to demonstrate that the class members have suffered the same injury ... This does not mean merely that they have all suffered a violation of the same provision of law" (Wal-Mart, Inc. v. Dukes, 2011, p. 2551). "Without some glue holding together the alleged reasons for those decisions, it will be impossible to say that examination of all the class members' claims will produce a common answer to the crucial discrimination question" (Wal-Mart, Inc. v. Dukes, 2011, p. 2545). The Court explained that the proposed Dukes class fell short of such rigorous standard of commonality. Dukes clearly imposed a higher burden on plaintiffs to satisfy the class certification under Rule 23(a).

The Court also decided that claims seeking monetary relief would not be appropriate under Rule 23 (b)(2), "at least where the monetary relief is not incidental to the requested injunctive or declaratory relief" (Wal-Mart, Inc. v. Dukes, 2011, p. 2545). The opinion expressly distinguished the purpose of Rule 23(b)(2) from that of Rule 23(b)(3):

Rule 23(b)(2) applies only when a single, indivisible remedy would provide relief to each class member ... [I]ndividualized monetary claims belong instead in Rule 23(b)(3), with its procedural protections of predominance, superiority, mandatory notice, and the right to opt out. (Wal-Mart, Inc. v. Dukes, 2011, p. 2545)

While most federal circuits have recognized that a Rule 23 class action and an FLSA collective action are mutually exclusive, the hybrid collective action may allow a defendant to raise some unique defenses to Rule 23 class certification because of the intertwined nature of the lawsuit. First, the conditional certification for $\$ 216$ (b) claim would provide the defendant with ample opportunities to scrutinize some individual putative class members at an early stage of the litigation. The scrutiny may produce a good amount of evidence to challenge Rule 23 class certification based on the lack of commonality under Dukes criteria. Second, assuming that the District Court grants the FLSA conditional certification, the defendant may argue that the state law claim under Rule 23 is no longer "superior" to the FLSA collective action pursuant to Rule 23(b)(3) (Lampe \& Rossman, 2005). Third, the opt-in mechanism of the FLSA can be used against Rule 23 class certification. Opt-in rates in FLSA collective actions are typically low, mostly between 10-20\% (Seyfarth Shaw, 2012). If the number of claimants who have opted-in is small, it is arguable that the class at issue is presumably not so "numerous" that "joinder is [not] impracticable" (FRCP Rule 23(a)(1)). Lastly, the defendant may request the District Court not to exercise supplemental jurisdiction over state law claims under Rule 23. This move, however, might be a double-edged sword since the defendant may need to litigate separate lawsuits on essentially identical legal issues in multiple venues (Lampe \& Rossman, 2005).

In Chen, if the FLSA claim proceeded, a pool of opt-in claimants would have formed. Then MLB might be able to gather evidence to demonstrate that the opt-in volunteers were not so "similarly situated" (FRCP § 216(b)) that the class would not satisfy the stringent standards of the commonality articulated in Dukes. As the FLSA action continues, MLB could argue that the class action might not be "superior" to the FLSA claim for the purpose of Rule 23(b)(3). Assuming that the opt-in rate was not extraordinarily high, MLB may also have argued that the putative class is not large enough to constitute the Rule 23 class action. If the 
plaintiff's FLSA claim was not dismissed on 12(b)(6) motion, the defendant could appeal to the court's discretion not to exercise its supplemental jurisdiction on the state law claim. But this might have resulted in multivenue litigation, which might not be really advantageous to the defendant.

Rule 68 Pick-Off: Genesis Healthcare, Co. v. Symczyk (2013). So-called "pickoff" under the FRCP Rule 68 ("offer of judgment") is a powerful defensive weapon that can neutralize an FLSA hybrid action at an early stage of the lawsuit. Rule 68 states, "a party defending against a claim may serve on an opposing party an offer to allow judgment on specified terms, with the costs then accrued . . . . The clerk must then enter judgment" (FRCP Rule 68(a)). Since the FLSA collective action mostly starts with a small number of named plaintiffs, the defendant can make an offer to pay them an amount that fully satisfies all of their individual claims owed before the certification of the collective group. The offer then eliminates the controversy between the parties that is required for the subject matter jurisdiction of the court under the Article III $\S 2$ of the Constitution. Essentially, the case becomes no longer justiciable since there is no more "cases or controversies" to be decided.

In Genesis Healthcare, Co. v. Symczyk (2013), a registered nurse filed an FLSA collective action on the ground that the employer automatically deducted $30 \mathrm{~min}$ of time worked per shift for meal breaks against a group of employees even though "they performed compensable work during those breaks" (Genesis Healthcare, Co. v. Symczyk, 2013, p. 1527). The employer offered $\$ 7,500$ for the unpaid wages, reasonable attorney fees, costs, and other expenses. Because the employer's offer eliminated "justiciable case or controversy" between the parties, the court dismissed the plaintiff's FLSA claim for lack of subject matter jurisdiction. The Third Circuit reversed the decision in finding that such procedural maneuver would likely frustrate the goals of the collection action system under the FLSA. In a 5-4 decision, the Supreme Court ruled that "to invoke federal-court jurisdiction, a plaintiff must demonstrate that he possesses a legally cognizable interest or personal stake in the outcome of the action" (Genesis Healthcare, Co. v. Symczyk, 2013, p. 1528; citing Camreta v. Greene, 2010). The opinion announced that "[w]hile the FLSA authorizes an aggrieved employee to bring an action on behalf of himself and other employees similarly situated ... the mere presence of collective-action allegations in the complaint cannot save the suit from mootness once the individual claim is satisfied" (Genesis Healthcare, Co. v. Symczyk, 2013, p. 1529). However, Genesis did not decide whether the employer's Rule 68 offer must actually be accepted by employees or making such offer is enough to eliminate "case or controversy." As of this writing, the actual acceptance of such offer is required in the Second and Sixth Circuit whereas merely making the offer appears to be enough in the Third, Fourth, Fifth, and Seventh Circuits.

In spite of the circuit split over whether the offer must actually be accepted, the pick-off under Rule 68 is an effective procedural weapon available to defendants in FLSA collective actions pursuant to Genesis. In anticipation of the pick-off, plaintiffs in FLSA cases are usually compelled to move for the conditional certification and following proceedings in an expedited pace. For instance, in Chen, the plaintiff filed a motion for conditional certification of the FLSA collective action only 8 days after from the filing of the complaint. 


\section{Conclusion and Implications}

This article explored various aspects of the hybrid collective action pursuant to the FLSA and FRCP Rule 23 in light of Chen v. MLB. In Chen, while the defendant successfully dismissed the FLSA collective action by using the Rule 12(b)(6) motion, the type of controversy in and around the sport industry would likely continue. In fact, many sport organizations might not qualify for the seasonal establishment exception used by MLB in the case. Although the case did not examine whether the volunteers are employees for the purpose of the FLSA, the relevant provisions of the statute, DOL regulations, and case law suggest that volunteers working for most of nonprofit organizations and for-profit enterprises might not be exempt. In Chen, the Rule 23 class action for the state labor law claim was dismissed without prejudice. Thus, the plaintiff may retry the claim in other venues.

In particular, under Smith v. Bayer Corp. (2011), Chen might not have preclusive effects even if the District Court denied the Rule 23 class certification as long as the law firm can recruit a different plaintiff for another copycat lawsuit against MLB. In Smith (2011), the U.S. District Court of Minnesota enjoined a West Virginia state court from considering a class action filed against Bayer for sale of an allegedly hazardous drug, Baycol. The District Court granted the injunction on the ground that the federal court had denied a class certification in a related lawsuit brought by a different plaintiff alleging similar claims against the same defendant. Essentially, the federal court's opinion stated that the injunction was appropriate to prevent the relitigation of the issue that had been decided already, i.e., collateral estoppel. The Court of Appeals for the Eighth Circuit affirmed. The Supreme Court granted a writ of certiorari in consideration of the circuit split on the matter (See In re Baycol Products Litigation, 2010; See also In re Ford Motor Co., 2006). At issue was whether the relitigation exception to the Anti-Injunction Act (28 U.S.C. $\S 2283$ ) permits the District Court in Smith to enjoin the state court proceedings.

The Anti-Injunction Act (28 U.S.C. §2283) states that "[a] court of the United States may not grant an injunction to stay proceedings in a State court except as expressly authorized by Act of Congress, or where necessary in aid of its jurisdiction, or to protect or effectuate its judgments." The statute indicates that the Framers intended to protect the "dual system of federal and state courts" (Chick Kam Choo v. Exxon Corp., 1988, p. 146) so that state courts "shall remain free from interference by federal courts" (Atlantic Coast Line R. Co. v. Locomotive Engineers, 1970, p. 282). "Any doubts as to the propriety of a federal injunction against state court proceedings should be resolved in favor of permitting the state courts to proceed." (Atlantic Coast Line R. Co. v. Locomotive Engineers, 1970, p. 297). Thus, the Act has explicitly prohibited federal courts from limiting state courts' jurisdiction, in general.

One of the exceptions to the Act is the so-called relitigation exception. The exception is based on the "well-recognized concepts of claim and issue preclusion" (Smith v. Bayer Corp., 2011, p. 2375). The rule is narrowly interpreted, however. A party may claim the issue preclusion only if the issue decided in the prior federal court proceedings is identical with the one presented to the state court. In addition, the plaintiff against whom the rule is asserted must have been in the earlier proceedings as a party. Given the limited applicability of the exception, the Supreme Court in Smith decided that the District Court abused its discretion by enjoining the state 
court from considering the issue of class certification. The opinion articulated that the issue presented to the state tribunal was not the same as the one examined by the District Court since Rule 23 of the FRCP had legal standards different from West Virginia class action statutes for the purpose of class certification. Moreover, the opinion stated that Smith was "neither a party nor the exceptional kind of nonparty who can be bound" to the federal court's decision (Smith v. Bayer, 2011, p. 2376).

In consideration of Smith (2011), MLB might not be able to assert the collateral estoppel defense in case of a copycat hybrid action brought by a different plaintiff in another jurisdiction. Even if Chen or the law firm decides not to pursue the claim against MLB anymore, other law firms and lawyers may bring isomorphic copycat actions against MLB or other sport and entertainment organizations that frequently rely on volunteers and unpaid interns' labor.

Sport and entertainment organizations need to be more proactive and vigilant in using volunteers and interns. First, the simplest and most effective course of action that the league would take is the compliance of the law by using paid workers and conducting periodic audits to preempt possible violations of the law. Previously explained, the FLSA is a proplaintiff statute in terms of its burden of proof and other procedural mechanisms. Given the availability of the hybrid collective action, some FLSA claims may impose a huge financial risk on the employers.

Second, recent case law suggests that class action and/or class arbitration waiver might be useful. In AT\&T, LLC. v. Conception (2011), the Supreme Court upheld the enforceability of an anticlass action provision that compelled arbitration in lieu of Rule 23 class action. The Court ruled that the Federal Arbitration Act of 1925 has preempted the California state law making the anticlass action provision unconscionable. The Court went even further by upholding an anticlass arbitration provision in American Express Co. v. Italian Colors Restaurant (2013). Given the cases, sport and entertainment organizations may incorporate anticlass action or class arbitration provisions into their liability waiver used for internship or volunteer programs. The following waiver might be an instructive example:

No Class Actions. You may only resolve disputes with us on an individual basis, and may not bring a claim as a plaintiff or a class member in a class, consolidated, or representative action. Class arbitrations, class actions, private attorney general actions, and consolidation with other arbitrations aren't allowed. (Dropbox, March 24, 2014)

In spite of the aforementioned preemptive measures, litigation might be unavoidable. Then the defensive tactics discussed earlier in light of Dukes and Genesis Healthcare might be effective.

\section{References}

Adams v. Detroit Tigers, 961 F. Supp. 176 (E.D. Mich. 1997).

Adkins v. Children's Hospital, 261 U.S. 525 (1923).

Adler, S.I., \& Prentice, L.F. (2012). Civil practice: Class actions and the FLSA. New Jersey Law Journal, 208(8), 618-619.

Altria Group v. Good, 555 U.S. 70 (2008).

Amchem Products, Inc. v. Windsor, 521 U.S. 591 (1997).

American Express Co. v. Italian Colors Restaurant, 133 S. Ct. 2304 (2013). 
Anti-Injunction Act, 28 U.S.C. § 2283 (West 2014)

Atlantic Coast Line R. Co. v. Locomotive Engineers, 398 U.S. 281 (1970).

AT\&T, LLC. v. Conception, 563 U.S. 321 (2011).

Babcock v. Computer Assocs. Int'l, 212 F.R.D. 126 (E.D.N.Y. 2003).

Banyai v. Mazur, 205 F.R.D. 160 (S.D.N.Y. 2002).

Bellas v. CBS, Inc., 201 F.R.D. 411 (W.D. Pa. 2000).

Bickerton v. Rose, 2013 N.Y. Misc. LEXIS 2762 (2013)(settled June 28, 2013).

Bridewell v. Cincinnati Reds, 155 F. 3 d 828 (6th Cir. 1998).

Calder, R. (2014, March 26). Judge tosses FanFest volunteer suit against MLB. New York Post. Retrieved from http://nypost.com/2014/03/26/judge-tosses-fanfest-volunteersuit-against-mlb/.

Camreta v. Greene, 131 S. Ct. (2010).

Chen v. Major League Baseball, No. 13 Civ. 5494, 2014 U.S. Dist. LEXIS 42078 (S.D.N.Y. March 26, 2014).

Chen v. Major League Baseball (Complaint), (S.D.N.Y. filed August 7, 2013) (No. 13 Civ. 5494).

Cheskin, M. R., Samuel, R. J., Cheung, S. T., \& Burke, C. M. (2006). Strategies for avoiding and defending FLSA wage/hour class actions. Paper presented at 2006 Labor \& Employment Seminar: Important Legal and Ligation Issues Facing Employers.

Chick Kam Choo v. Exxon Corp., 486 U.S. 140 (1988).

Cleary, M. M. (1995). Who is employed in "administrative capacity" within exemption, under 29 U.S.C.A. $\$ 213($ a)(1), from minimum wage and maximum hours provisions of Fair Labor Standards Act. 124 A.L.R. Fed. 1.

Cleveland v. City of Elmendorf, 388 F.3d 522 (5th Cir. 2004).

Code of Federal Regulations, 29 C.F.R. § 553.101 (West 2014).

Code of Federal Regulations, 29 C.F.R. $\$ 779.23$ (West 2014)

Code of Federal Regulations, 29 C.F.R. $\$ 779.203$ (West 2014)

Davenport v. Elite Model Management Corp., Civ. No. 13 CV 1061 (filed February 15, S.D.N.Y. 2013).

Department of Labor. (2009). Employment Relationships under the Fair Labor Standards Act. Retrieved from http://www.dol.gov/whd/regs/compliance/whdfs13.htm.

Department of Labor. (2010). Fact Sheet \#71: Internship Programs under the Fair Labor Standards Act. Retrieved from http://www.dol.gov/whd/regs/compliance/whdfs71.htm.

Dropbox (March 24, 2014). Terms of Service. Retrieved from https://www.dropbox.com/ terms2014?view_en.

Eisen v. Carlisle \& Jacquelin, 391 F.2d 555 (2d Cir. 1968).

Evans v. U.S. Pipe \& Foundry Co., 696 F.2d 925 (11 Cir. 1983).

Fair Labor Standards Act of 1938, 29 U.S.C. $\S \S 201$ et seq. (West 2014).

Federal Rules of Civil Procedure, Rule 12(b)(6) (West 2014).

Federal Rules of Civil Procedure, Rule 23 (West 2014).

Federal Rules of Civil Procedure, Rule 68(a) (West 2014).

General Telephone Co. v. Falcon, 457 U.S. 147 (1982).

Genesis Healthcare, Co. v. Symczyk, 133 S. Ct. 1523 (2013).

Gillis v. Hoechst Celanese Corp., 1992 U.S. Dist. LEXIS 4984 (E.D. Pa. 1992). (2011, p. 2551)

Glatt v. Fox Searchlight Pictures, 293 F.R.D. 516 (S.D.N.Y. 2013).

Grayson v. K Mart Corp. 79 F.3d 1086 (11th Cir. 1996).

Gregory, D.L. (1998). The problematic employment dynamics of student internship. Notre Dame Journal of Law, Ethics \& Public Policy, 12(1), 227-64.

Guarino, G. A. (1985). Typicality requirement of Rule 23(a)(3) of Federal Rules of Civil Procedure as to class representative in class action based on unlawful discrimination. 74 A.L.R. Fed. 42.

Hallissey v. America Online, Inc., 99-CIV-3785, 2006 U.S. Dist. LEXIS 12964 (S.D.N.Y. 2006)

Harris v. Palm Springs Alpine Estates, 329 F.2d 909 (9th Cir. 1964).

Hill v. U.S., 751 F.2d 810 (6th Cir. 1984). 
Hoffman-La Roche, Inc. v. Sperling, 493 U.S. 165 (1989).

In re Baycol Products Litigation, 593 F.3d 716 (8th Cir. 2010).

In re Ford Motor Co., 471 F.3d 1233 (11th Cir. 2006).

Isaacson v. Penn Community Services, Inc., 450 F.2d 1306 (4th Cir. 1971).

Jeffery v. Sarasota White Sox, 64 F.3d 590 (11th Cir. 1995).

Jordan, K. (1993). Note: FLSA restrictions on volunteerism: The institutional and individual costs in a changing economy. Cornell Law Review, 78, 302-335.

Kalet, J.E. (1990). Age discrimination in employment law (2nd edition). Washington D.C.: Bureau of National Affairs.

Lampe, M.W., \& Rossman, E.M. (2005). Procedural approaches for countering the duel-filed FLSA collective action and state-law wage class action. The Labor Lawyer, 20, 311.

Laroque v. Domino's Pizza, LLC, 557 F. Supp. 2d 346 (EDNY, 2008).

Major League Baseball. (2014). 2013 All Star FanFest. MLB.com News. Retrieved from http://mlb.mlb.com/mlb/events/all_star/y2013/fanfest/faq.jsp.

Matsushita Electric Industrial, Co. v. Epstein, 516 U.S. 367 (1996).

Maye, M. (2013). Bringing outside world into the classroom: Practicum experience in sports management. The International Journal of Sport \& Society, 3, 19-29.

Murphy, B.S., \& Azoff, E.S. (1987). Guide to Wage and Hour Regulation 3. Bethesda, MD: Bureau of National Affairs.

Murray v. Auslander, 244 F.3d 807 (11th Cir. 2001).

Nerland v. Caribou Coffee Co. 564 F. Supp. 2d 1010 (D. Minn. 2007).

New York Labor Law, Article 6, §§ 190 et seq. (West 2014)

New York Labor Law, Article 19, §§ 650 et seq. (West 2014)

New York State Department of Labor Regulations, N.Y. Comp. Codes Rule \& Regulations, Title 12, Part 142 et seq. (West 2014)

Pani v. Empire Blue Cross Blue Shield, 152 F.3d 67 (2d Cir. 1998).

Realite v. Ark Restaurants Corp., 7 F. Supp. 2d 303 (S.D.N.Y. 1998).

Richards v. FleetBoston Fin. Corp., 235 F.R.D. 165 (D. Conn. 2006).

Rubinstein, M.H. (2006). Our nation's forgotten workers: The unprotected volunteers. University of Pennsylvania Journal of Labor and Employment Law, 9(1), 147-184.

Rules Enabling Act, 28 U.S.C. § 2072 (West 2014).

Schoepfer, K.L., \& Dodds, M. (2010). Internships in sport management curriculum: Should legal implications of experiential learning result in the elimination of the sport management internship? Marquette Sports Law Review, 21(1), 183-201.

Senne v. Major League Baseball, (N.D. Cal. 2014 filed Feb. 17, 2014) (Case No. 3:14-cv00608-JCS).

Seyfarth Shaw, L.L.P. (2012). Wage \& hour collective and class litigation webinar series. Retrieved from http://www.seyfarth.com/dir_docs/publications/WHPLITpartII.pdf

Smith v. Aon Corp., 238 F.R.D. 609 (N.D. Ill. 2006).

Smith v. Bayer Corp., 131 S. Ct. 2368 (2011).

Smith, S.J., \& Jalbert, C.M. (2011). Certification - 216(b) collective actions v. Rule 23 class actions \& enterprise coverage under the FLSA. Paper presented at the American Bar Association Section of Labor and Employment Law Fifth Annual Conference, Seattle, WA.

Sova, K.A. (2013). How to use unpaid interns the right way (and keep litigation at bay). NYSBA Entertainment, Arts and Sports Law Journal, 24(2), 21-2.

Spelfogel, E. J. (2009). Emerging trends in class action and collective action lawsuits. NYSBA L\&E Newsletter, 34(3), 23-26.

Thompson v. RelationServe Media, Inc., 610 F.3d 628 (11th Cir. 2010)

Tittle v. Enron Corp. (In re Enron Corp. Sec.), 228 F.R.D. 541 (S.D. Tex. 2005).

Tony \& Susan Alamo Foundation v. Secretary of Labor, 471 U.S. 290 (1985).

Vadino v. Valey Engineers, 903 F.2d 253 (3rd Cir. 1990).

Wal-Mart, Inc. v. Dukes, 131 S.Ct. 2541 (2011). 
Walling v. Portland Terminal Co., 330 U.S. 148 (1947).

Wang v. Fento Fallon Corp. No.1:2012cv05188 (filed July 3, S.D.N.Y. 2012) (settled September 18, 2012).

Wang v. Hearst Corp., 293 F.R.D. 489 (S.D.N.Y. 2013).

West Coast Hotel Co. v. Parrish, 300 U.S. 379 (1937).

Williams v. Mohawk Industries, Inc., 568 F.3d 1350 (11th Cir. 2009). 